\title{
The errors of EFL students' TOEFL iBT integrated writing task
}

\author{
Nurhayati Irmawan ${ }^{1}$, Rahmi Aulia Nurdini ${ }^{2}$ \\ 1,2 Bina Sarana Informatika University, Indonesia \\ 1'nurhayati.nhi@bsi.ac.id, ${ }^{2}$ rahmi.rau@bsi.ac.id \\ *) correspondence: nurhayati.nhi@bsi.ac.id
}

\begin{abstract}
Reading, Listening, Speaking and Writing are four skills tested in TOEFL iBT. The two types of questions in the writing task of TOEFL iBT are independent and integrated. Focusing on the integrated task in which test-takers require to read a passage, to listen to a lecture related to the topic of the reading and to summarize the listening by explaining how it relates to the points in the reading (Peterson, 2007:8). This research analyzed the errors of students' writing production of integrated task. The research samples of the task were taken from 7 (seven) TOEFL iBT candidates. Examining 14 integrated tasks, this study categorized the errors into three major categories: grammar, mechanics, and content errors. This study found that most frequent grammatical errors were in the verb (22\%), agreement $(20 \%)$, and followed by a noun (14\%). The findings of mechanic errors are mostly in the use of capitalization at the beginning of a sentence. In the part of punctuation errors, it was found that the omission of a comma as a frequent error. The last results are content errors which consist of plagiarism; own idea addition; question addressing in which if the test takers' response focuses on one of the two passages and completely ignores the other one; and missed information in which testtakers are unable to absorb key information from reading and listening passage. It is expected that these findings enable TOEFL iBT tutors to recognize candidates' problems and improve their teaching approach to reach better results.
\end{abstract}

Keywords: error analysis; TOEFL iBT; integrated writing task; summarizing

\section{INTRODUCTION}

Rilcy and Wyatt (2009:6) stated that ETS launched the "next generation TOEFL" in 2005. This new version of the test combines all four language skills (Reading, Listening, Speaking, Writing) and is internet-based (iBT), which makes it more widely accessible all over the world. There are 4 skills tested in TOEFL iBT: reading, listening, speaking, and writing. One of the skills is supposed to be the most complicated one is writing tasks as test-takers are expected to equip themselves with some proficient English skills.

As it is known that there are two types of questions in the writing task: independent and integrated. Focusing on the integrated task, test-takers require to read a passage and listen to a lecture that is related to the topic of the passage. They will be asked to summarize the listening passage and explain how it relates to the points in the reading passage (Peterson, 2007:8). It means that test takers are supposed to have 3 skills : reading, listening, and writing. To do writing tasks, they must also have technical skills of writing such as planning, organizing, and revising as well as the mechanics of the writing such as spelling, punctuation, and capitalization (Richards and Renandya in Keyvanfar and Khoskhou, 2015:61).

Considering that many skills are to be equipped to do the integrated writing task, the researchers as the TOEFL iBT tutors as well, intend to investigate detailed errors made on the participants' integrated writing task. Thus, error analysis is used to examine their writing production. 


\section{TOEFL and TOEFL iBT in brief}

According to Rilcy and Wyatt (2009:6), TOEFL is administered by ETS (Educational Testing Service), one of the world's leading organization in the field of educational and psychometric research, based in Princeton, New Jersey. Since it was introduced in 1964, TOEFL has become a global standard for the assessment of English language proficiency. It aims at measuring non-native speaker's ability to use English to communicate effectively in college and university settings.

As cited in Keyvanfar and Khoshkhou (2015:62), previously the writing component of the TOEFL contained only one independent task. However, this task was seriously questioned since it did not reflect the exact genre used in real academic settings (Ohkubo, 2009). Hamp-Lyons and Kroll (in Cumming, Grant, Mulcahy-Ernt, \& Powers, 2005) have censured then administered the writing component of the TOEFL test because it by no means assessed the types of writing students have to perform in academic settings. Cumming, et al. (2005:2) challenged the educational relevance, authenticity, and content validity of the TOEFL test.

The TOEFL iBT test consists of four sections: Reading, Listening, Speaking, and Writing. The entire test is about 4 hours long, and all sections are taken on the same day. The TOEFL iBT test measures all four language skills that are important for effective communication, emphasizing the test taker's ability to use English effectively in academic settings (Educational Testing Service, 2012).

The TOEFL Test complies with ETS standards for quality and fairness, ensuring that it is a highly reliable instrument for assessing English proficiency. In addition to the TOEFL Test, ETS has designed a wide range of nationally and internationally recognized qualification and aptitude examination. Zareva (in Keyvanfar and Khoshkhou, 2015:62) explains that the new version of the TOEFL is not only an updated version of the previous one but a test that involves new components, such as integrated speaking and writing sections which assess the test taker's ability to combine information from more than one source and to communicate about it.

On ETS Propell of TOEFL iBT Workshop Manual (n.d.:41) mentions that there two types of writing task in TOEFL iBT :

\section{The Integrated Writing Task}

It displays a 230-to-300 reading passage for 3 minutes and follows with a 2-minutes recording (200 to 300 words) by a speaker who discusses the same topic from a different perspective and contributes additional information. This task also redisplays the reading passage and presents a writing prompt/question. Then, it allows 20 minutes for writing and revising the response to the question.

Test-takers will read and take notes on the first passage, then listen to take notes on the second passage. Next, they will respond to a prompt in 150 to 225 words explaining and not be penalized for writing a longer response. Fink, L., et al (n.d.. page 10) in How to Ace TOEFL Writing, the question of integrated writing task follows one of several formulas such as:

a) Summarize the points made in the lecture, being sure to explain how they cast doubt on specific points made in the reading passage.

b) Summarize the points made in the lecture, being sure to explain how they challenge specific claims/arguments made in the reading passage.

c) Summarize the points made in the lecture, being sure to specifically explain how they answer the problems raised in the reading passage.

d) Summarize the points made in the lecture, being sure to specifically explain how they support the explanations in the reading passage.

e) Summarize the points made in the lecture, being sure to specifically explain how they strengthen points made in the reading passage.

Following Rilcy and Wyatt (2009:135), typical mistakes are found in integrated writing tasks are about (1) incomplete content;(2) text copying, (3) remain neutral, and (4) difficult words. Besides, as cited in Keyvanfar and Khoshkhou (2015:67-68) that the typical errors of this writing are in (1) plagiarism; (2) own idea addition, and (3) question addressing. Moreover, 
Suhartoyo (2017) revealed that the most complicated problem in building writing task was about thinking critically.

\section{The Independent Writing Task.}

As mentioned in the TOEFL IBT Workshop Manual (p.42), this task requires writing an essay that states, explains and supports the writer's opinion on a given issue. The writer should write a minimum 300 words. It allows 30 minutes total for preparation, writing, and revision.Test takers will develop and organize thoughts thoroughly. They not only provide thoughtful support for opinions and choices buat also write clearly and accurately.

Another thing which is also important in an independent task is the structure of an essay. As stated in Peterson (2007), an essay should have an introduction, a body, and a conclusion. In the Introduction, it should get the reader's attention and tell the reader what the essay is about and give the reader any special information that guides the reader to the body of your essay. In the case of a TOEFL essay, the introduction should be one paragraph containing four to five sentences. The body of the essay should be made up of one to three paragraphs that contain the ideas to be communicated to the reader. The conclusion, which should be one paragraph, summarizes what is written in the body.

\section{Error Analysis}

According to Gorbet (in Khansir, 2012:1029), some errors can be attributed to weaknesses or failure of memory. He added that the theory of error analysis proposes that to learn a language, a person creates a system of "rules ${ }^{\text {ee }}$ from the language data to which he is exposed; and this system enables him to use it. Based on Sharma (in Khansir, 2012:1029), "Error analysis can thus provide strong support to remedial teaching", he added that during the teaching program, it can reveal both the successes and the failures of the program. Dulay et al (1982) mentioned that the term "error" to refer a systematic deviation from a selected norm or set of norms. Error analysis is useful in second language learning because this will reveal to us- teachers, syllabus designers, and textbook writers and the problem areas. It can be used to design remedial exercises and focus more attention on the trouble spots. Corder (1974:125) stated that "The study of errors is part of the investigation of the process of language learning. In this respect, it resembles methodologically the study of the acquisition of the mother tongue. It provides us with a picture of the linguistic development of a learner and may give us indications as to the learning process". Besides, errors also can be made by the first language interference (Septiana, 2020). Richards et al (1992) mentioned the study of errors are used to (1) identify strategies which learners use in language teaching, (2) identify the causes of learners' errors, and finally (3) obtain information on common difficulties in language learning as an aid to teaching or in development of teaching materials ( cited in Khansir 2008).

As Richards (in Khansir, 2012:1029) classified errors observed in the acquisition of English as a second language as follows:

1. Overgeneralization, covering instances where the learners create a deviant structure on the basis of their experience of other structure of the target language;

2. Ignorance of rule restriction, occurring as a result of failure to observe the restrictions or existing structures;

3. Incomplete application of rules, arising when the learners fail to fully develop a certain structure required to produce acceptable sentences;

4. False concepts hypothesized, deriving from faulty comprehension of distinctions in the target language.

As Erdoğan (in Keyvanfar and Khoshkhou, 2015:64) believes that errors function shows as feedback in the sense that they reflect whether the teaching style of the teacher is effective and what changes it still needs. Errors, he adds, can identify the points and areas which need further attention. He concludes that the study targeting EA is aimed at investigating the language learners' strategies, the 
reason why language learners make errors, and the common difficulties in learning and development of remedial materials.

All these are considered for the researchers to do an error analysis of the students' TOEFL iBT integrated writing tasks to help language tutors including the reserachers themselves to reach better compehension of the most common typical errors on their wiritng production.

\section{METHODS}

\section{Research Design}

This research was carried out by using descriptive qualitative method looking into EFL students' errors in their integrated writing task of TOEFL iBT. Nassaji (2015:129) stated that the goal of descriptive research is to describe a phenomenon and its characteristics. Qualitative research, however, is more holistic and often involves a rich collection of data from various sources to gain a deeper understanding of individual participants, including their opinions, perspectives, and attitudes. Qualitative research collects data qualitatively, and the method of analysis is also primarily qualitative

Lambert V. and Lambert C (2012:255) stated that qualitative descriptive studies are the least "theoretical" of all of the qualitative approaches to research. In other words, a qualitative descriptive study may have grounded theory overtones, because it used constant comparative analysis when examining the data. However, a qualitative descriptive study is not grounded theory, because it does not produce a theory from the data that were generated.

In this study, the researchers used the EFL students' writing integreated task of TOEFL iBT to be analyzed into 3 categories: grammar, mechanics, and content errors.

\section{Data Collection Technique}

According to Lambert and Lambert C (2012:256), data collection of qualitative descriptive studies focuses on discovering the nature of the specific events under study. Thus, data collection involves minimal to moderate, structured, open-ended, individual, or focus group interviews. However, data collection also may include observations, and examination of records, reports, photographs, and documents. Data analysis of qualitative descriptive research, unlike other qualitative approaches, does not use a pre-existing set of rules that have been generated from the philosophical or epistemological stance of the discipline that created the specific qualitative research approach.

This research was conducted to the EFL students of Elokuensi, an International Language Center which is located in West Jakarta, Indonesia. 7 students were in the Advanced Level of the course. The two were university students and the others were senior high students. The students as the participants had about several years of English learning experience at school and at Elokuensi itself. The samples of the research were taken from all the participants' TOEFL iBT integrated writing tasks. The sample was clinically collected as it was specifically collected for research purposes. Based on Ellis's (2008) list of factors to be considered when collecting learner language samples, the following table was drawn.

TABLE 1. Characteristics of Learner Language Sample of the Study

\begin{tabular}{|c|c|c|}
\hline Factors & Variables & Description \\
\hline \multirow[t]{2}{*}{ Learner } & 1.Proficiency level & Intermediate, using TOEFL \\
\hline & 2.Language learning experience & $\begin{array}{l}\text { English language classes } \\
\text { months) }\end{array}$ \\
\hline Language & 1.Medium & Written \\
\hline \multirow[t]{2}{*}{ Sample } & 2.Genre & Integrated Writing Task \\
\hline & 3.Content & Academic \\
\hline Production & 1.Planned & $\begin{array}{l}\text { The discourse produced allowed } \\
\text { for } 20 \text {-minute-task completion }\end{array}$ \\
\hline
\end{tabular}




\section{Data Analysis}

The participants took Mini Tests and Complete test of Longman Student CD-ROM for the TOEFL iBT $2^{\text {nd }}$ Edition by Deborah Phillips (2008) and Cambridge Preparation for the TOEFL Test, $4^{\text {th }}$ Edition by Jolene Gear and Richard Gear (2007). There were 14 papers collected as the research samples taken randomly from three types of tests. The writing tasks of the participants were rated using ETS' TOEFL iBT writing rubrics (see Appendix A) and the scores (see Appendix B). It is legitimate to conclude that the participants were intermediate in terms of language proficiency level.

Throughout this study, the writing tasks of these candidates were scored by the TOEFL iBT tutor who acts as one of the researchers. The analysis of the writing samples was carried out by both of the researchers. The writers here focus on analyzing one of the writing tasks which was the integrated one. At first, grammatical mistakes of the sentences of all the participants were identified. The grammatical errors were then categorized and named based on grammatical rules. Investigating the writing tasks for any possible error, the researcher and her colleague investigated the writing tasks in terms of the mechanics of the writing and the content. Briefly, the errors of integrated tasks were subsequently placed in three major categories of (1) grammatical errors, (2) mechanical errors, and (3) content errors.

\section{RESULTS AND DISCUSSION}

In the previous study, Keyvanfar and Khoshkou (2015) investigated the errors of the TOEFL iBT candidates' writing tasks, integrated and independent task. In addition, the writers also have conducted the same study but only focused on the independent task. In this study, the analysis still concerns with the errors of integrated writing tasks that were classified into three: grammar, mechanics, and content errors.

\section{Grammar Errors}

Table 2 provides the grammar errors of the EFL students' TOEFL iBT integrated writing task. It contains definitions and the error results for each identified error category at the grammatical level. The errors include verb, agreement, noun, sentence structure, article or determiner preposition, connectives, wrong word, parallelism structure, and word choice.

\section{TABLE 2. Grammar Errors}

\begin{tabular}{|c|c|c|c|}
\hline No. & $\begin{array}{c}\text { Grammatical } \\
\text { Errors }\end{array}$ & Definition & Error Result \\
\hline 1 & Verb & $\begin{array}{l}\text { Errors in } \\
\text { passive/active, infinitive, } \\
\text { modals, tense, gerund, } \\
\text { modals }\end{array}$ & $\begin{array}{l}\text { 1. Beck Steven is fulfill fulfills this criteria too... } \\
\text { 2. The head of faculty did not does not agree ... } \\
\text { 3. He is prepare prepared to be a journalist. } \\
\text { 4. Becky (is) also active ... } \\
\text { 5. He does is not in the campus.. } \\
\text { 6. He joins in student counselor } \\
\text { 7. He also joins photography class } \\
\text { 8. He deide decides to join ... } \\
\text { 9. He spend spends his time ... } \\
\text { 10. He also join joins journalism major... } \\
\text { 11. We read is depend depends on .... } \\
\text { 12. This land bridge (is) used to connect ... } \\
\text { 13. Since it is can still be used... } \\
\text { 14. They (are) already in the middle semester... } \\
\text { 15. Some points in the reading passage is fault and } \\
\text { questionable if be it is compared with .... } \\
\text { 16. Reading passage do not concluded } \\
\text { 17. There are two reasons that (is) fault in the reading } \\
\text { passage. } \\
\text { 18. His grade is really good, all (grades are) A .... }\end{array}$ \\
\hline
\end{tabular}


Irmawan, N. and Nurdini, R., A.

19. Her grades are pretty good, all (grades are) A and B and (,) A grades (are) for subject ...

\begin{tabular}{|c|c|c|}
\hline Agreement & $\begin{array}{l}\text { Errors in subject-verb, } \\
\text { number, and pronoun } \\
\text { agreement }\end{array}$ & $\begin{array}{l}\text { 1. Based on the lecturer, the first book tell about ... } \\
\text { 2. The question that pop pops up ... } \\
\text { 3. Back Steven also have has many ... } \\
\text { 4. Someone who joins a lot of activities... } \\
\text { 5. He feels like kind .... } \\
\text { 6. This story also tall talks about .... } \\
\text { 7. It is called the intrinsic motivation which allows } \\
\text { someone... } \\
\text { 8. There are two candidates .... } \\
\text { 9. He also have has a good ... }\end{array}$ \\
\hline
\end{tabular}

\begin{tabular}{|c|c|c|c|}
\hline 3 & Nouns & $\begin{array}{l}\text { Errors in using countable } \\
\text { (singular-plural) and } \\
\text { uncountable nouns. }\end{array}$ & $\begin{array}{l}\text { 1. Beck Steven is fulfill this criteria too... } \\
\text { 2. The head of faculty did not does not agree ... } \\
\text { 3. He is preprepared to be a journalist. } \\
\text { 4. Becky (is) also active ... } \\
\text { 5. He toes is not in the campus... } \\
\text { 6. He joins in student counselor... } \\
\text { 7. He also joins photography class... } \\
\text { 8. He decide decides to join ... } \\
\text { 9. He spend spends his time ... } \\
\text { 10. He also join joins journalism major... } \\
\text { 11. We read is depend depends on .... } \\
\text { 12. Since it is can still be used... } \\
\text { 13. This land bridge (is) used to connect ... } \\
\text { 14. They (are) already in the middle semester... } \\
\text { 15. Some points in the reading passage is fault and } \\
\text { questionable if be it is compared with .... } \\
\text { 16. Reading passage do not concluded ... } \\
\text { 17. There are two reasons that (is) fault in the reading } \\
\text { passage... } \\
\text { 18. His grade is really good, all (grades are) A .... } \\
\text { 19. Her grades are pretty good, all (grades are) A and B } \\
\text { and (,) A grades (are) for subject ... }\end{array}$ \\
\hline 4 & $\begin{array}{l}\text { Sentence } \\
\text { Structure }\end{array}$ & $\begin{array}{l}\text { Any errors in main \& } \\
\text { subordinating clause } \\
\text { structure }\end{array}$ & $\begin{array}{l}\text { 1. Two biography books about the president but two of } \\
\text { them are true from the true story. } \\
\text { 2. But the second book tell tells about .... } \\
\text { 3. Finally, the last criterion that committee need the } \\
\text { improve the life of people is community. } \\
\text { 4. After a week later, the committee came .......because the } \\
\text { campus.... } \\
\text { 5. The first book contains early life of person business } \\
\text { problem that happen the persen the discipline problem } \\
\text { that he has in elementary school, and his ... } \\
\text { 6. But, there are more differences with fraternal twins } \\
\text { because they do tø of nature and genre. }\end{array}$ \\
\hline 5 & $\begin{array}{l}\text { Article/ } \\
\text { Determiner } \\
\text { Preposition }\end{array}$ & $\begin{array}{l}\text { Any omitted, incorrect, } \\
\text { or unnecessary use of the } \\
\text { article "the" and } \\
\text { other determiners } \\
\text { Any omitted } \\
\text { unnecessary, and } \\
\text { incorrect uses of verb \& } \\
\text { adjective } \\
\text { prepositions }\end{array}$ & $\begin{array}{l}\text { 1. As we know (the) history is not a brief... } \\
\text { 2. From the reading passage given, we know... } \\
\text { 3. The content thide of each book must be different... } \\
\text { 4. Even though that the person may not do it. } \\
\text { He spends most of time on in campus }\end{array}$ \\
\hline 7 & Connectives & $\begin{array}{l}\text { Any omitted, incorrect or } \\
\text { unnecessary use of } \\
\text { connectives }\end{array}$ & $\begin{array}{l}\text { 1. Someone who involve the community to help (and) } \\
\text { improve the life of people. }\end{array}$ \\
\hline
\end{tabular}


expressing cause \& effect, 2. He joins in student counselor, soccer team, violin team, result an well he also joins photography class

\begin{tabular}{|c|c|c|c|}
\hline & & $\begin{array}{l}\text { expressing cause \& effect, } \\
\text { result }\end{array}$ & $\begin{array}{l}\text { 2. He joins in student counselor, soccer team, violin team, } \\
\text { anly that as well he also joins photography class }\end{array}$ \\
\hline 8 & Wrong word & $\begin{array}{l}\text { Incorrect spelling } \\
\text { resulting in formation of } \\
\text { meaningful actual English } \\
\text { word }\end{array}$ & 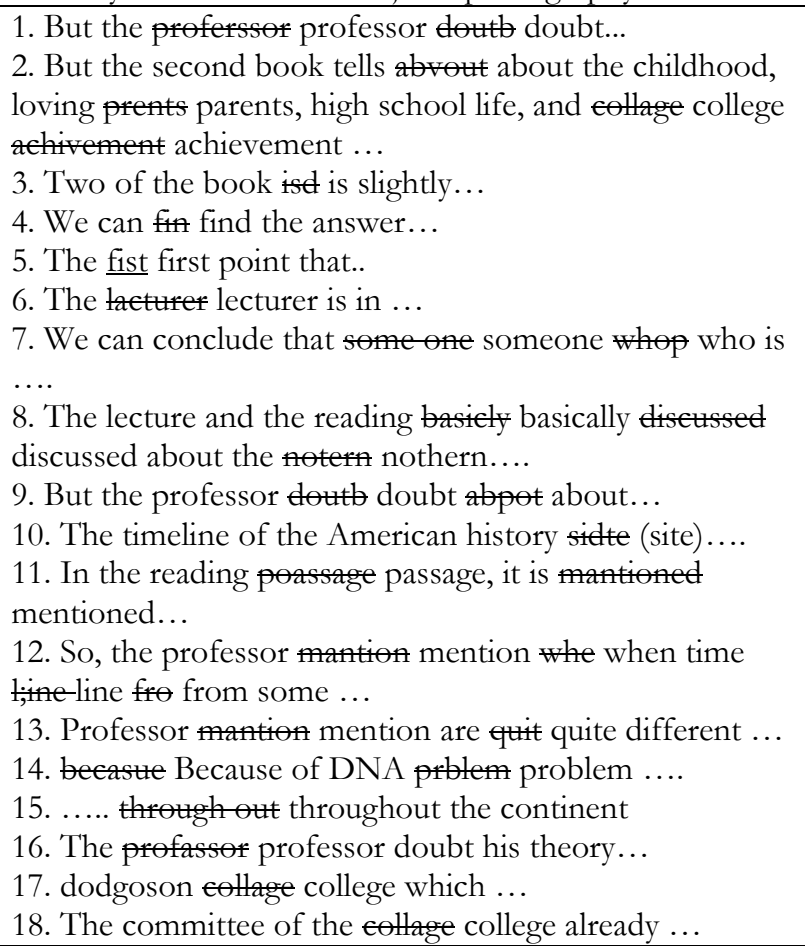 \\
\hline 9 & $\begin{array}{l}\text { Parallelism } \\
\text { Structure }\end{array}$ & $\begin{array}{l}\text { Any errors in the use of } \\
\text { components in a } \\
\text { sentence that are } \\
\text { grammatically the same; } \\
\text { or similar in their } \\
\text { construction. }\end{array}$ & $\begin{array}{l}\text { 1. He is worthy because his study major is journalism, many } \\
\text { a and b in his grade. Attend a lot of activities, he spent of } \\
\text { his time in campus and doing some charity for hospital in } \\
\text { his free time -> He is worthy because he took journalism } \\
\text { as his major, attend a lot of activities, spend of his time in } \\
\text { campus, and do some charity for hospital in his free time. } \\
\text { 2. After he grown up, he feel not did not feel really like to } \\
\text { sing because he needed to live up .... } \\
\text { 3. She even enjoyed singing whenever she could even she } \\
\text { does did not get anything } \\
\text { 4. Some opinion are not accepted by the faculty group while } \\
\text { some de are not } \\
\text { 5. He spends most of time in campus, and If he is does not, } \\
\text { he sill spend spends his time ... }\end{array}$ \\
\hline 10 & Word Choice & $\begin{array}{l}\text { Sound, and meaning } \\
\text { Any errors in selecting } \\
\text { precise words that } \\
\text { create meaning on your } \\
\text { audience. }\end{array}$ & $\begin{array}{l}\text { 1. He spends his time at a hospital to } \\
\text { do... } \\
\text { 2. There are two kind types of motivation... } \\
\text { 3. The next plan from administrator is } \\
\text { 4. So, tet's the following explanation who ... } \\
\text { 5. Instead of raising their own } \\
\text {. }\end{array}$ \\
\hline
\end{tabular}

TABLE 3. The Frequency and Percentages of the Grammatical Errors of Integrated Task

\begin{tabular}{cccc}
\hline No. & Errors & Frequency & Percentage \\
\hline $\mathbf{1}$ & Verb & 19 & $20 \%$ \\
\hline $\mathbf{2}$ & Agreement & 21 & $22 \%$ \\
\hline $\mathbf{3}$ & Noun & 13 & $14 \%$ \\
\hline $\mathbf{4}$ & Sentence Structure & 6 & $6 \%$ \\
\hline $\mathbf{5}$ & Article/ Determiner & 4 & $4 \%$ \\
\hline $\mathbf{6}$ & Preposition & 1 & $1 \%$ \\
\hline $\mathbf{7}$ & Connectives & 2 & $2 \%$ \\
\hline $\mathbf{8}$ & Wrong word & 18 & $19 \%$ \\
\hline
\end{tabular}




\begin{tabular}{cccc}
\hline $\mathbf{9}$ & Pararelism Structure & 5 & $5 \%$ \\
\hline $\mathbf{1 0}$ & Word Choice & 5 & $5 \%$ \\
\hline & Total Errors & $\mathbf{9 4}$ & $10 \%$ \\
\hline
\end{tabular}

There were 94 grammar errors identified in the integrated task, $20 \%$ of verb errors; $22 \%$ of agreement errors; $14 \%$ of noun errors, $6 \%$ of sentence structure errors; $4 \%$ of the article or determiner errors; $1 \%$ for Preposition; $2 \%$ of connectives errors, $19 \%$ of wrong word error, $5 \%$ of parallelism structure error, and the last is $5 \%$ of word choice errors. The most frequent errors are found from the agreement category, and the fewest frequency ones are founded from preposition and connectives. There is the same error frequency that is from parallelism structure and word choice categories.

Keyvanfar's and Khoshkou's findings (2015) showed that eight categories of grammatical errors were in the two tasks of TOEFL iBT writing. Nevertheless, this study found 10 categories of grammatical errors. The additonal errors were noun, word choice and paralellism structure without part of speech errors.

\section{Mechanics Errors}

Besides grammatical errors, another kind of errors in writing task that is mechanics Errors. It consists of capitalization and punctuation errors. The following explanation of the error categories, definitions, and the example of this level.

1. Capitalization errors: All uses of small letters for capital letters and unnecessary uses of capitalization, for examples:
a) Based on the lecturer...
b) We can find the answer...
c) The fist first point that...

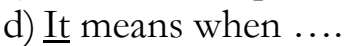
e) That one of the reasons why...
f) Beck Steven fulfills ....
g) The next plan from....

2. Punctuation errors: all cases of omission, incorrect use of period, colon, semicolon, omitted, and incorrect punctuation in subordinate clauses. All required but missed punctuation are indicated in parentheses, for example:

a) Based on the lecturer (,) the first book tells ........(with a comma)

b) So we can conclude that....(with a comma)

c) Some history events are recorded some of the other history event events are ignored (with a comma)

d) Firstly, from the reading passage we can see...(with a comma)

e) Finally the last criterion ....(with a comma)

f) Because of DNA problem (,) the professor doubt this ....(with a comma)

g) Finally he got a procedur to sign a $\ldots . . . . . .$. (with comma)

h) Firstly, from the story we can ... (with a comma)

i) After he grown up he felt not ....(with comma)

j) After a week later the committee came .....(with a comma)

k) She even enjoyed singing whenever she could. even she does did not get anything (without full stop)

1) Sometimes she felt like not doing ....(with comma)

m) From the listening passage we know that ....(with a comma)

n) So from the listening I already hear I know that every book... (with a comma)

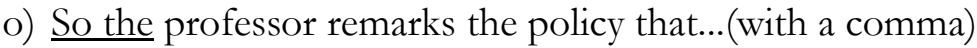

p) Second reason fraternal (with comma) twins have the same DNA. While (without full 
stop) identical twins have the different DNA.

q) So there are two reasons ...(with a comma)

r) First they have the same character ....and second they can be ....(with a comma)

s) But there are more ....(with a comma)

t) First reason the identical twins ...(with a comma)

As for the mechanics errors, most of the capitalization errors were at the beginning of the sentence. In total, there were 6 instances found in this study. Among these writing productions, some students showed occasional awareness that capital letters are always used in the beginning of a sentence. Another error of capitalization was in the use of Proper noun, using the name of the person which is Beck Steven. This result was a bit different from the previous writer's (2019) and Keyvanfar and Khoshkou's (2015) researches in which it mentioned that major error of capitalization was in the use of a letter of 'I' as a subject pronoun.

In the part of punctuation, the omission of a comma (,) was the most error found in this study). This omission was repeated 16 times; 7 adverb phrases placed in the beginning (in samples a, d, f, j, l, m, n); 6 after conjunctions (in samples b, e, g, h, o, p); 2 in the subordinate/independent clause (in samples c and i). Another punctuation error in the omission of full stop (.) in which it was placed in the middle of a sentence (in samples $\mathrm{k}$ and p).

\section{Content Errors}

At the content level, the writers found some errors in the students' integrated writing tasks of TOEFL iBT. Based on Peterson (2007:8), the integrated writing task requires test takers' to read a passage and listen to a lecture that is related to the topic of the reading and able to summarize the listening passage and explain how it relates to the points in the reading passage. The suggested length of their written response is between 150-225 words. The test takers must remember to make sure that their response relates to the questions posed. This is not writing an exercise that asks for their opinion. They are being asked to explain the points they have heard. Another guidance is also the ETS rubrics of integrated tasks (see Appendices A), the content of writing productions were investigated to determine if they were mannerly produced and appropriately reflected the content desired.

Rilcy and Wyatt (2009:135) mention that typical mistakes are found in integrated writing tasks are about (1) incomplete content;(2) text copying, (3) remain neutral, and (4) difficult words. Also, as cited in Keyvanfar and Khoshkhou (2015:67-68) that the typical errors of this writing are in (1) plagiarism; (2) own idea addition, and (3) question addressing.

Below are the investigations of the content errors based on the guidances above:

1. Plagiarism or text copying: It referred to all sentences/phrases taken intact and unaltered from the reading and/or listening passages. It was found in two students' underlined writing production $(14 \%)$ as the followings:

a) Dodgson College which is a small private institute of higher education just received a huge bequest from one of the former students. They quickly split the committee into two factions. One of the factions led by the administrator and the other faction lead by the head of the faculty. (Longman Mini Test 5 )

b) Finally the administrators wanted to spend the rest of the bequest on pay rises for them because the campus pays was ten percent below the national average. (Longman Mini Test 3)

c) Both agree to the meaning of deindividualization, which states that people tend to lose their individuality when they are in group, and the meaning of polarization, which states a like-minded people in a group tend to find an extreme decision than one might find alone. (Longman Mini Test 5) 
2. Own idea addition: This type of error includes all sentences reflecting personal ideas and conclusions made based on personal understanding rather than what the reading and listening passages reflected. The words/phrases/sentences below are the personal ideas of the students.

a) So from the listening i already hear I know that every book with different writer have different result and volume. (Longman Mini Test 7)

b) Second reason fraternal twins have the same DNA, while identical twins have the different DNA. (Cambridge Practice 6)

c) The question that pops up in our mind is how can it be true but two of the books are slightly different. (Longman Mini Test 7)

From the illustration above, there was $21 \%$ of participants who put their own idea in their responses.

3. Question addressing

Rilcy and Wyatt (2009: 135) states that incomplete content happens if the test takers' response focuses on one of the two passages and completely ignores the other one. Khoshkou and Keyvanfar (2015:68) stated that this kind of mistake referred to questions addressing, they mentioned that the questions given are mainly in three formats. 1) the question requires summarizing the information of the reading and the listening, 2) the listening passage introduces an idea or example in disagreement to what was stated in the reading, hence casting doubt on the point in the reading, 3) the listening and reading are complementary in that they both support the same view, with the listening usually providing an example and/or an additional reason, point, etc.

It was found that there were two students' writing production (Mini Test 1 and 7 ) which ignored the reading passage in her response as one of the students was distracted with the question asking for what effect the information provides in the listening passage. Another finding was about the student was not able to synthesize the points in the reading and listening passage as he did not understand or familiar with the topic. As a result, the response of his writing (Cambridge Practice 7) provided little meaningful or relevant coherent from the lecture. Finally there were 3 students' responses (21\%) who did not adress questions.

\section{Missed information}

This type included all the writing responses in which the test takers miss some information from reading and listening passage. The results shows that two students' writing production $(14 \%)$ was incomplete because of missing another part in listening and reading passage as the key information (Complete Test 1, Longman).

It can be concluded that the content errors of the students' integrated tasks were about plagiarism, own idea addition, question addressing, and missed infomation. This findings are mostly in line with Khoshkou's and Keyvanfar's (2015) mentioning the first three content errors.

\section{CONCLUSION}

The analysis of this study results was compared to the previous study carried out by Khoshkou and Keyvanfar (2015) in which their investigation was for both integrated and independent tasks. The findings of grammar errors in this study are a bit different from the previous study. It shows that agreement was major in grammar errors. It was also found that there were three additional grammar errors: noun, parallelism structure, and word choice, and deletion of part speech errors.

Mechanic errors were found in the uses of capitalization and punctuation errors. The use of capital letters at the beginning of the sentence was the most error in punctuation. Moreover, 
punctuation errors were about the use of a comma (,) which was mostly forgotten to be placed after conjunctions and adverb phrase.

An interesting comparison is that Khoshkou and Keyvanfar do not provide missed information as the content error in the integrated task. However, the rest of the content errors were corresponding to the results of this study: plagiarism, own idea addition, and question addressing.

From this study, it is expected that the results can be the guidance for TOEFL iBT tutors in teaching integrated writing tasks. Paraphrasing becomes the solution of plagiarism error and it was in line with Ohkubo (in Khoshkou and Keyvanfar, 2015:70) mentioning the importance of paraphrasing in academic settings. In addition, own idea addition is another content error and from this study, the tutors need to urge the participants to avoid their personal ideas or conclusion in this task. Furthermore, to be able to synthesize the points from reading and listening passage is another need to be noticed as 3 participants were not able to do so. One important thing that it was found that missed information is newly added as the content error.

\section{REFERENCES}

Al-Khresheh, M.H. (2016). A Review Study of Error Analysis Theory. International Journal of Humanities and Social Science Research, 2, 49-59.

Cumming, A., Grant, L., Mulcahy-Ernt, P., \& Powers, D. E. (2005).Monograph Series: A teacherVerification Study of Speaking and Writing Prototype Tasks for a New TOEFL. ETS TOEFL

Educational Testing Service. (2012). The Official Guide to the TOEFL TEST. Fourth Edition. McGraw Hill Education,

.Ellis, R. (2008). The study of second language acquisition (2nd ed.). UK: Oxford University Press.

Erdoğan, V. (2005). Contribution of error analysis to foreign language teaching. Mersin University Journal of the Faculty of Education, 1(2), 261-270.

Fink, L., et al. (n.d) How to Ace TOEFL Writing, p.10. https://toefl.magoosh.com/toefl-writingebook/

Gallagher, Nancy (2016). DELTA's Key to the TOEFL iBT. Complete Skill Practice. Delta Publishing Company.

Keyvanfar, A. and Khoshkhou, R.V. (2015). Error Taxonomy of TOEFL iBT Writing: An Iranian Perspective. Journal of Language and Translation Vol.5, No.2 (10), pp.61-75.

Khansir, A.A. (2012). Error Analysis and Second language Acquisition. Theory and Practice in Language Studies, Vol. 2, No. 5, pp. 1027-1032, May 2012 (C) 2012 ACADEMY PUBLISHER Manufactured in Finland. DOI:10.4304/tpls.2.5.1027-1032

Lambert V, Lambert C. Qualitative Descriptive Research: An Acceptable Design. Pacific Rim International Journal of Nursing Research [Internet]. 1 [cited 4Dec.2019];16(4):255-6. Available from: https://www.tci-thaijo.org/index.php/PRIJNR/article/view/5805

Munadia (2016). Thesis: An Analysis of EFL Students' Difficulty in the TOEFL structure abd written expression Section. The Faculty of Education and Teacher Training. Ar-Ranity State Islamic University, Darussalam, Banda Aceh.

Nassaji, H. (2015) Language Teaching Research: Qualitative and Descriptive Research: Data Type versus Data Analysis Vol. 19(2) 129-132. sagepub.co.uk/journalsPermissions.nav

DOI: $10.1177 / 1362168815572747$ ltr.sagepub.com

Ohkubo, N. (2009). Validating the integrated writing task of TOEFL internet-based test (iBT):

Linguistic analysis of test-takers' use of input material. Melbourne Papers in Language Testing, 14(1), 1-31.

Ospina, Sonia (2009). Qualitative Research. Robert F.Wagner Graduate School of Public Service. New York University.

Peterson (2007). Peterson's Master TOEFL Writing Skills. A Nelnet company.

Rilcy, R. And Wyatt, R. (2009). Achieve TOEFL iBT: Test-preparation guide. Marshal Cavendish Education. 
Septiana, A. R. (2020). The indonesian grammatical interference on EFL students' writing. Journal of Research on English and Language Learning (J-REaLL). https://doi.org/10.33474/j-reall.v1i1.5610 Suhartoyo, E. (2017). the Importance of Critical Thinking Competence : an Investigation of Students' Writing Experiences. International Seminar on Language, Education, and Culture.

Zareva, A. (2005). What is new in the New TOEFL-iBT2006 test format? Electronic Journal of Foreign Language Teaching, 2, 45-57. Retrieved June 29, 2010, from http://e-flt.nus.edu.sg/ Propell Workshop for TOEFL IBT. English Language Learning. Teacher Workshop. ETS. https://www.ets.org/toefl/teachers_advisors/propell_workshop 


\section{Appendix A}

\section{TOEFL iBT ${ }^{\bullet}$ Test}

\section{Integrated WRITING Rubrics}

\begin{tabular}{|c|c|}
\hline SCORE & TASK DESCRIPTION \\
\hline 5 & $\begin{array}{l}\text { A response at this level successfully selects the important information from the lecture and coherently and } \\
\text { accurately presents this information in relation to the relevant information presented in the reading. The } \\
\text { response is well organized, and occasional language errors that are present do not result in inaccurate or } \\
\text { imprecise presentation of content or connections. }\end{array}$ \\
\hline 4 & $\begin{array}{l}\text { A response at this level is generally good in selecting the important information from the lecture and in } \\
\text { coherently and accurately presenting this information in relation to the relevant information in the reading. } \\
\text { but it may have minor omission inaccuracy, vagueness, or imprecision of some content from the lecture or } \\
\text { in connection to points made in the reading. A response is also scored at this level if it has more frequent } \\
\text { or noticeable minor language errors, as long as such usage and grammatical structures do not result in } \\
\text { anything more than an occasional lapse of clarity or in the connection of ideas. }\end{array}$ \\
\hline 3 & $\begin{array}{l}\text { A response at this level contains some important information from the lecture and conveys } \\
\text { some relevant connection to the reading, but it is marked by one or more of the following: } \\
\text { - Although the overall response is definitely oriented to the task, it corveys only vague, global, unclear, or } \\
\text { somewhat imprecise connection of the points made in the lecture to points made in the reading. } \\
\text { - The response may omit one major key point made in the lecture. } \\
\text { - Some key points made in the lecture or the reading or connections between the two, may be incomplete, } \\
\text { inaccurate, or imprecise. } \\
\text { - Errors of usage and/or grammar may be more frequent or may result in noticeably vague } \\
\text { expressions or obscured meanings in corveying ideas and connections. }\end{array}$ \\
\hline 2 & $\begin{array}{l}\text { A response at this level contains some relevant information from the lecture, but is marked by signifi- } \\
\text { cant language difficulties or by significant omis sion or inaccuracy of important ideas from the lecture } \\
\text { or in the connections between the lecture and the read ing; a response at this level is marked by one or } \\
\text { more of the following: } \\
\text { - The response significantly misrepre sents or completely omits the overall connection between the lecture } \\
\text { and the reading. } \\
\text { - The response significantly omits or significantly misrepre sents important points made in the lecture. } \\
\text { - The response contains language errors or expressions that largely obscure connections or meaning at key } \\
\text { junctures or that would likely obscure understanding of key ideas for a reader not already familiar with } \\
\text { the reading and the lecture. }\end{array}$ \\
\hline 1 & $\begin{array}{l}\text { A response at this level is marked by one or more of the following: } \\
\text { - The response provides little or no meaningful or relevant coherent content from the lecture. } \\
\text { - The language level of the response is solow that it is difficult to derive meaning. }\end{array}$ \\
\hline 0 & $\begin{array}{l}\text { A response at this level merely copies sentences from the reading rejects the topic or is othenwise not } \\
\text { connected to the topic, is written in a foreign language, consists of keystroke characters, or is blank. }\end{array}$ \\
\hline
\end{tabular}

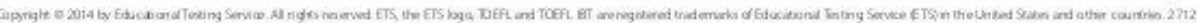

\section{(⿶SS) TOEFL}




\section{ETS. TOEFL}

Converting Rubric Scores to Scaled Scores

Writing and Speaking Sections of the New TOEFL iBT Test

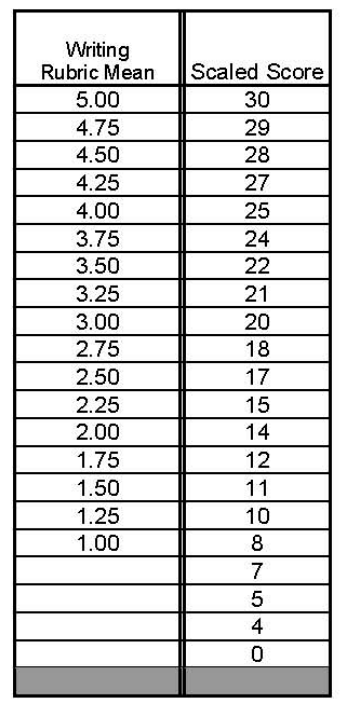

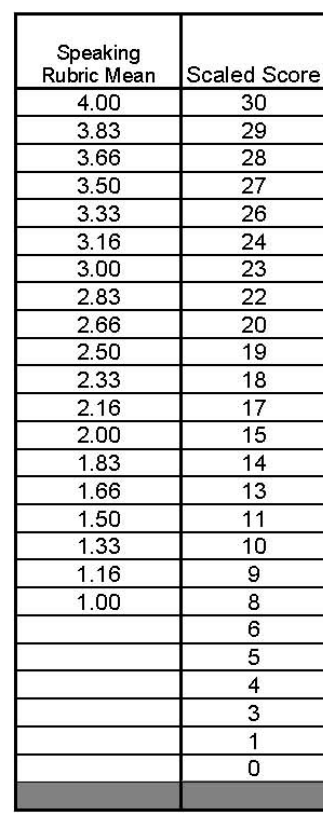

Performance on the Speaking and Writing sections of the next generation TOEFL test is evaluated based on scoring rubrics of $0-5$ for each of the two Writing items and $0-4$ for each of the 6 Speaking items. The tables show how the mean rubric score of the two writing items and the mean rubric score of 6 speaking items are converted to a scaled score of $0-30$ 